\title{
Magnitude of Deep-focus Earthquakes in and near Japan
}

\author{
by \\ W. Inouye \\ Meteorological Research Institute, Tokyo \\ (Received January 10, 1959)
}

\begin{abstract}
The writer tried to obtain the same $M$ as those given by the Pasadena seismological laboratory for the deep-focus earthquakes in and near Japan by using the seismological data obtained at Japanese stations.

And the writer succeeded in finding a method to get $M$ with a difference of \pm 0.3 unit of magnitude as compared with the Pasadena determination.

It is shown that the calculated $\log A / T-\Delta$ curves for deep earthquakes of various depths on the basis of Norman Ricker's wavelet theory fit well with the observed values.

It is shown that the magnitude of deep earthquakes can be given by the formula,

$$
0.63 M=\log A_{0} / T_{0}+\alpha(H),
$$

so far as the magnitude does not exceed 7 .

If $M$ exceeds 7 , we must use the other formula,

$$
\left\{0.63+0.08\left(\log A_{0} / T_{0}+\alpha(H)-4.4\right)\right\} M=\log A_{0} / T_{0}+\alpha(H) .
$$

And $\alpha(H)$ is given by the formula

$$
\alpha(H)=2.5 \log t_{0}-2.8,
$$

where $t_{0}$ is the travel time of the $S$ phase at the epicenter.

It is shown that the station corrections for deep earthquakes are quite different from those for shallow earthquakes.

Some examples are shown to suggest that there is the azimuthal factor among the observed $\log A / T$, having some intimate connections with the mechanism of the occurrence of the earthquakes.

Some theoretical considerations are made on the formula
\end{abstract}

$$
\log A_{0} / T_{0}=0.63 M-\alpha(H) .
$$

\section{Introduction}

The magnitudes were given for many deep-focus earthquakes which occurred in and near Japan by the Pasadena seismological laboratory (See B. GutenberG and C.F. Richter, 1954). 
B. Gutenberg and C.F. Richter (1956) say, "Until 1954, the writers generally reported magnitudes for large deep shocks, and for large shallow teleseisms as determined from body waves, effectively in terms of $M_{S}$, first determining $m_{B}$ and then correcting to $M_{S}$ by applying equation

$$
M_{S}-m_{B}=a\left(M_{S}-b\right),
$$

or an earlier approximation to it. The correction was usually applied only to shocks of magnitude 7 or over."

Further, they say, "For a number of years reductions were carried out with $a=1 / 4, b=7$, converting values of $m_{B}$ into the corresponding $M_{S}$."

Where $M_{S}$ is the magnitude determined from the amplitudes of surface waves for shallow teleseisms and $m_{B}$ is found from the amplitude/period ratio of body waves for teleseisms, shallow and deep-focus. As shown above, we must remember that the magnitude of a deep-focus earthquake is given effectively in terms of $M_{S}$.

Prof. H. Honda (1951), Dr. T. Hirono and Mr. Y. Iwai (1952), Dr. K. Wadati and Dr. T. Hirono (1956) and Mr. K. Katsumata (1958) tried to obtain the same $M$ as those given by the Pasadena seismological laboratory as close as possible for the deep-focus earthquakes in and near Japan by using the seismological data obtained at Japanese stations.

They succeeded in finding methods to get $M$ with a difference of \pm 0.3 unit of magnitude as compared with the Pasadena determination.

The writer, also, studied the same subject taking it into consideration that the Pasadena magnitude was given effectively in terms of $M_{S}$. The writer considered the relation between the common logarithm of the amplitude/period ratio at the epicenter and the corresponding magnitude, and obtained an equation

$$
\log A_{0} / T_{0}=0.63 M-\alpha(H) .
$$

Where $A_{0}$ and $T_{0}$ are respectively the maximum amplitude in microns and the period in seconds of the wave with the maximum amplitude at the epicenter and $\alpha(H)$ is a constant for a given focal depth $H$. And the writer succeeded in getting $M$ with the same accuracy as his predecessors.

\section{Station correction}

As is well known, the common logarithm of the amplitude/period ratios obtained at many stations in case of a deep earthquake scatter about its mean value at each epicentral distance more intensely than in case of a shallow earthquake.

The reason of the scattering might be found in the difference among the geological structures around stations, that is the matter connected with the station correction, as well as in the azimuthal difference in the intensity of the wave emission at the hypocenter. The latter will be discussed in a later article.

After several trials, the writer determined the station correction to be added to $\log A / T$ observed at each station for deep earthquakes, and could lessen the scattering of the observed values to one half of the original one by applying these corrections. $A / T$ in $\mu / \mathrm{sec}$ is the mean value of the two horizontal components. 
The station corrections are shown in Table 1.

Table 1. Station correction $C$.

\begin{tabular}{|c|c|c|c|c|c|}
\hline Station & $C$ & Station & $C$ & Station & $C$ \\
\hline $\begin{array}{l}\text { Aikawa } \\
\text { Akita } \\
\text { Aomori } \\
\text { Chichibu } \\
\text { Choshi }\end{array}$ & $\begin{array}{l}+0.07 \\
-0.38 \\
-0.68 \\
-0.05 \\
-0.25\end{array}$ & $\begin{array}{l}\text { Kumagaya } \\
\text { Kumamoto } \\
\text { Kyoto } \\
\text { Maebashi } \\
\text { Matsumoto }\end{array}$ & $\begin{array}{l}-0.07 \\
-0.16 \\
+0.18 \\
+0.13 \\
+0.10\end{array}$ & $\begin{array}{l}\text { Osaka } \\
\text { Oshima } \\
\text { Saga } \\
\text { Sakata } \\
\text { Sapporo }\end{array}$ & $\begin{array}{l}-0.08 \\
-0.01 \\
-0.59 \\
-0.45 \\
-0.19\end{array}$ \\
\hline $\begin{array}{l}\text { Fukui } \\
\text { Fukushima } \\
\text { Fukuoka } \\
\text { Fukuoka(B) } \\
\text { Funatsu }\end{array}$ & $\begin{array}{r}+0.04 \\
-0.48 \\
+0.07 \\
0 \\
-0.15\end{array}$ & $\begin{array}{l}\text { Matsushiro } \\
\text { Matsuyama } \\
\text { Mishima } \\
\text { Mito } \\
\text { Miyako }\end{array}$ & $\begin{array}{l}+0.70 \\
+0.19 \\
-0.18 \\
-0.51 \\
-0.35\end{array}$ & $\begin{array}{l}\text { Sendai } \\
\text { Shionomisaki } \\
\text { Shimizu } \\
\text { Shirakawa } \\
\text { Shizuoka }\end{array}$ & $\begin{array}{l}-0.31 \\
+0.28 \\
+0.41 \\
-0.31 \\
+0.31\end{array}$ \\
\hline $\begin{array}{l}\text { Gifu } \\
\text { Hachinohe } \\
\text { Hamada } \\
\text { Hamamatsu } \\
\text { Hikone }\end{array}$ & $\begin{array}{l}+0.10 \\
-0.08 \\
+0.55 \\
+0.10 \\
-0.16\end{array}$ & $\begin{array}{l}\text { Miyazaki } \\
\text { Mizusawa } \\
\text { Mori } \\
\text { Morioka } \\
\text { Murotomisaki }\end{array}$ & $\begin{array}{l}+0.10 \\
-0.60 \\
-0.47 \\
-0.38 \\
+0.56\end{array}$ & $\begin{array}{l}\text { Sumoto } \\
\text { Takada } \\
\text { Tokyo } \\
\text { Tomie } \\
\text { Tomisaki }\end{array}$ & $\begin{array}{l}+0.51 \\
-0.25 \\
-0.06 \\
+0.82 \\
-0.09\end{array}$ \\
\hline $\begin{array}{l}\text { Hiroshima } \\
\text { Inawashiro } \\
\text { Ishinomaki } \\
\text { Kagoshima } \\
\text { Kakioka }\end{array}$ & $\begin{array}{l}+0.52 \\
-0.40 \\
-0.19 \\
-0.32 \\
-0.69\end{array}$ & $\begin{array}{l}\text { Nagano } \\
\text { Nagoya } \\
\text { Niigata } \\
\text { Numazu } \\
\text { Nagasaki }\end{array}$ & $\begin{array}{r}0 \\
-0.08 \\
-0.45 \\
-0.23 \\
+0.49\end{array}$ & $\begin{array}{l}\text { Toyama } \\
\text { Toyooka } \\
\text { Tsuruga } \\
\text { Ustunomiya } \\
\text { Uwajima }\end{array}$ & $\begin{array}{l}+0.21 \\
+0.24 \\
+0.25 \\
-0.55 \\
+0.01\end{array}$ \\
\hline $\begin{array}{l}\text { Kameyama } \\
\text { Kanazawa } \\
\text { Kobe } \\
\text { Kochi } \\
\text { Kofu }\end{array}$ & $\begin{array}{l}+0.14 \\
-0.09 \\
+0.26 \\
+0.46 \\
-0.16\end{array}$ & $\begin{array}{l}\text { Oita } \\
\text { Oiwake } \\
\text { Omaezaki } \\
\text { Onahama } \\
\text { Okayama }\end{array}$ & $\begin{array}{l}-0.35 \\
+0.02 \\
-0.24 \\
-0.83 \\
+0.13\end{array}$ & $\begin{array}{l}\text { Wajima } \\
\text { Wakayama } \\
\text { Yokohama } \\
\text { Yagi }\end{array}$ & $\begin{array}{l}-0.40 \\
+0.29 \\
-0.65 \\
+0.20\end{array}$ \\
\hline
\end{tabular}

The station corrections for many stations in Japan for shallow earthquakes have already been determined by various authors. Recently, Mr. M.IICHIKAWA (1958) determined them newly and compared them with those given by various authors.

The writer compared his station corrections for deep earthquakes with IcHIKAWA's for shallow earthquakes. The results are shown in Fig. 1, where the numerals on each station show the value obtained by subtracting the latter from the former. Therefore, the station which has a negative or a positive value is shaken by a deep earthquake respectively more intensely or less than in case of a shallow earthquake.

As will be seen from the figure, the stations in the east part of the main island and Kyushu have mainly negative

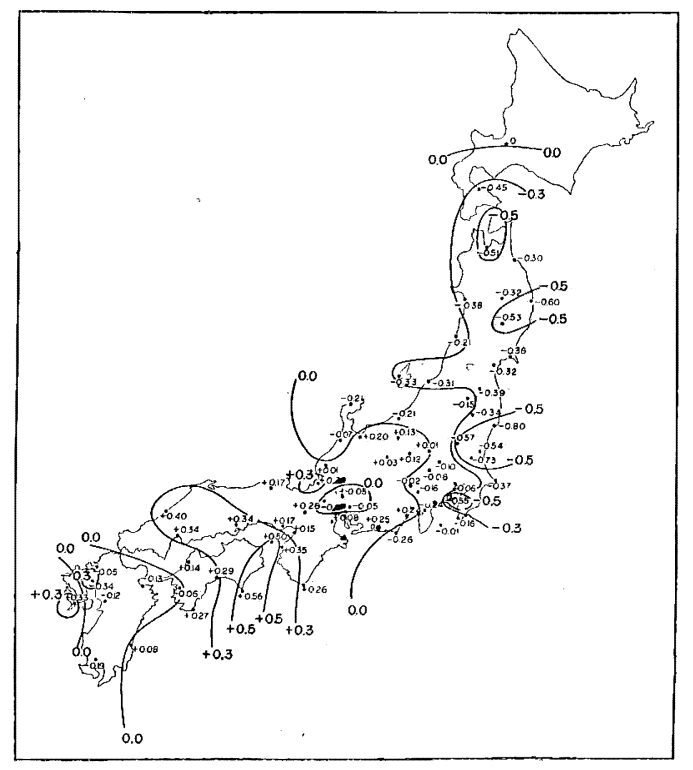

Fig. 1. Geographical distribution of (station correction for deep earthquakes)-(station correction for shallow earthquakes). 
values, and in the west part of the main island and Shikoku they mainly have positive values. The former regions correspond to the zones of abnormal seismic intensity well known in the case of a deep earthquake.

This fact seems to show that the station correction for deep earthquakes reflects deeper geological structures around each station than in case of shallow earthquakes.

\section{3. $\log \boldsymbol{A} / \boldsymbol{T}-\Delta$ curves for deep-focus earthquakes}

To obtain the common logarithm of the amplitude/period ratio at the epicenter of an earthquake from the data obtained at various epicentral distances, we must determine the standard $\log A / T-\Delta$ curve for each depth of the focus.

K. WADATI and T. Hrrono (1956) devised a method to obtain an attenuation coefficient as a function of depth, and showed in a figure the standard $\log A / T-\Delta$ curve for an earthquake of $H=240 \mathrm{~km}$ as an example. The curve given by them varies with $M$.

It seems to the writer that there are yet some ambiguities about the velocity and the attenuation coefficient of the medium at each depth in the upper part of the Earth. Moreover, the laws governing the attenuation of the wave travelling through the Earth are not well known.

N. RICkER (1949) summarized his wavelet theory on the propagation of shock waves in an absorbing medium as follows:

(1) It is the center of the wavelet which travels with the classical velocity of sound in the medium, this velocity being given by the square root of the elasticity over the density.

(2) The breadth of the wavelet, measured in second, say, is proportional to the square root of the propagation time of its center.

(3) The amplitude of the displacement-type wavelet decays as the wavelet advances through the Earth in such a manner that the amplitude is inversely

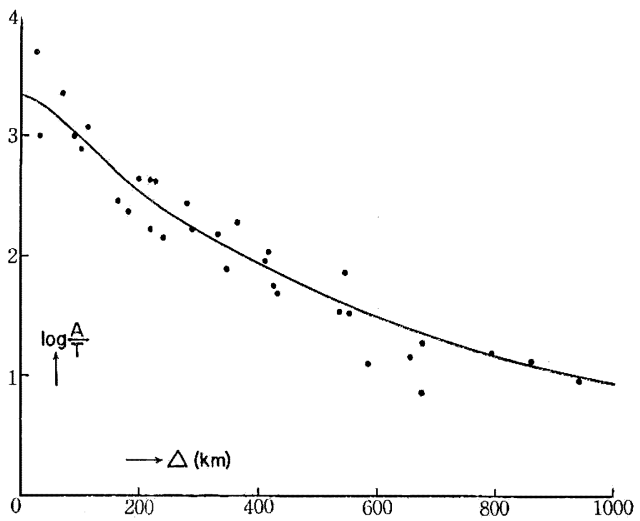

Fig. 2. Standard $\log A / T-\Delta$ curve and observed values of the earthquake on February 7, 1938, $H=100 \mathrm{~km}$.

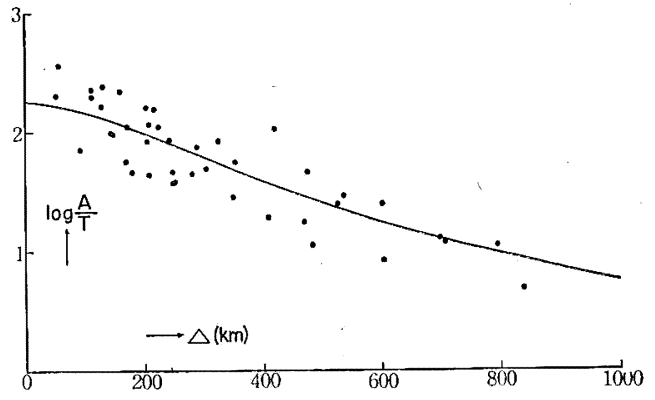

Fig. 3. Standard $\log A / T-\Delta$ curve and observed values of the earthquake on April 15, 1935, $H=230 \mathrm{~km}$. 
proportional to the $4 / 2$ power of the travel time of its center, etc.

By his theory, it is expected that the amplitude/period ratio decreases inversely proportional to the $5 / 2$ power of the travel time of the wave.

The writer calculated $\log A / T-\Delta$ curve for deep earthquakes of various depths on the basis of N. Ricker's theory, and compared them with the observed data corrected with the station factor. In general, the curves rather well fitted with the observed values. Some examples are shown in Figs. 2, 3 and 4.

We used the travel time of the $S$ phase given by Dr. K. Sagisaka and Mr. M. Takehana (1935) as the basis of the calculation, supposing that the wave with the maximum amplitude of a deep earthquake might be found in a group of $S$ waves, when observed at an epicentral distance less than about $1,000 \mathrm{~km}$.

Some examples of the travel time of the $S$ phase and the standard $\log A / T-A$ value calculated on the assumption that $A / T$ decreases inversely proportional to the $5 / 2$ power of the travel time of the $S$

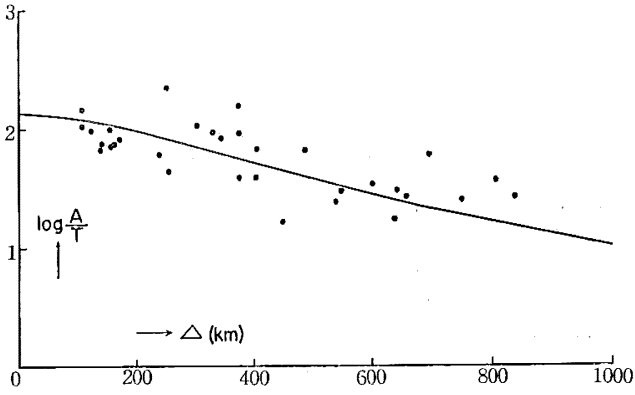

Fig. 4. Standard $\log A / T-\Delta$ curve and observed values of the earthquake on June, 30, 1931, $H=350 \mathrm{~km}$. phase are given in Table 2 . In the table, $\log A / T$ at the epicenter is taken as zero.

Table 2. Travel time of $S$ phase and the standard $\log A / T$.

\begin{tabular}{|c|c|c|c|c|c|c|c|c|c|c|}
\hline \multirow{2}{*}{$\begin{array}{c}\Delta \\
\mathrm{km}\end{array}$} & \multicolumn{2}{|c|}{$H=100 \mathrm{~km}$} & \multicolumn{2}{|c|}{$H=200 \mathrm{~km}$} & \multicolumn{2}{|c|}{$H=300 \mathrm{~km}$} & \multicolumn{2}{|c|}{$H=400 \mathrm{~km}$} & \multicolumn{2}{|c|}{$H=500 \mathrm{~km}$} \\
\hline & $t_{s}$ sec. & $-\log A / T$ & $t_{s} \mathrm{sec}$ & $\left|-\log _{A / T}\right|$ & $t_{s}$ sec. & $-\log _{A / T}$ & $t_{s} \mathrm{sec}$ & $\left|-\log _{A / T}\right|$ & $t_{s}$ sec. & $\mid-\log _{A / T}$ \\
\hline 0 & 25.6 & 0 & 47.9 & 0 & 69.4 & 0 & 89.7 & 0 & 108.3 & 0 \\
\hline 20 & 26.3 & 0.03 & 48.0 & 0 & 69.6 & 0.01 & 89.9 & 0.01 & 3.4 & 0 \\
\hline 40 & 27.7 & 09 & 49.0 & 0.03 & 70.1 & 0.02 & 90.2 & 0.01 & 08.7 & 0 \\
\hline 60 & 29.7 & 0.16 & 50.2 & 0.05 & 70.8 & 0.03 & 90.8 & 0.02 & 109.2 & 0.01 \\
\hline 80 & 32.3 & 0.25 & 51.7 & 0.09 & 71.7 & 0.04 & 91.6 & 0.03 & 109.8 & 0.01 \\
\hline 100 & 35.2 & 0.35 & 53.5 & 0.12 & 72.9 & 0.06 & 92.5 & 0.04 & 110.5 & 0.02 \\
\hline 140 & 42.2 & 0.54 & 57.7 & 0.20 & 75.9 & 0.10 & 94.8 & 0.06 & 112.3 & 0.04 \\
\hline 180 & 49.7 & 0.72 & 63.1 & 0.30 & 79.8 & 0.16 & 97.8 & 0.10 & 114.9 & 0.06 \\
\hline 220 & 57.4 & 0.88 & 69.5 & 0.41 & 84.5 & 0.22 & 101.4 & 0.14 & 117.7 & 0.09 \\
\hline 260 & 65.3 & 1.02 & 76.3 & 0.51 & 89.9 & 0.29 & 105.5 & 0.18 & 121.4 & 0.12 \\
\hline 300 & 73.2 & 1.14 & 83.6 & 0.61 & 95.7 & 0.35 & 110.3 & 0.23 & 125.4 & 0.16 \\
\hline 340 & 81.4 & 1.26 & 91.0 & 0.70 & 101.9 & 0.42 & 115.5 & 0.28 & 129.8 & 0.19 \\
\hline 380 & 89.9 & 1.37 & 98.5 & 0.78 & 108.3 & 0.49 & 121.0 & 0.33 & 134.5 & 0.23 \\
\hline 420 & 98.6 & 1.47 & 106.0 & 0.86 & 115.2 & 0.55 & 126.8 & 0.38 & 139.4 & 0.27 \\
\hline 460 & 107.4 & 1.56 & 114.0 & 0.94 & 122.2 & 0.62 & 132.8 & 0.43 & 144.5 & 0.31 \\
\hline 500 & 1 & 1.65 & 122.0 & 1.02 & 129.3 & 0.68 & 139.0 & 0.48 & 149.8 & 0.35 \\
\hline 580 & 135.2 & 1.81 & 138.2 & 1.15 & 143.9 & 0.80 & 152.0 & 0.58 & 161.0 & 0.43 \\
\hline 660 & 154.1 & 1.95 & 154.3 & 1.27 & 159.0 & 0.90 & 165.7 & 0.67 & 173.1 & 0.51 \\
\hline 740 & 172.8 & 2.08 & 171.0 & 1.38 & 174.3 & 1.00 & 179.8 & 0.76 & 185.7 & 0.58 \\
\hline 820 & 191.2 & 2. 18 & 188.0 & 1.49 & 190.0 & 1. 10 & 194.3 & 0.84 & 199.1 & 0.66 \\
\hline 900 & 2 & 2.28 & 205.2 & 1.60 & & 1. 19 & & 0.92 & & 0.73 \\
\hline 980 & & 2.42 & 222.6 & 1.67 & 222.5 & 1.27 & 223.9 & 1.00 & 226.9 & 0.80 \\
\hline 1060 & 245.1 & 2.45 & 239.8 & 1.75 & 238.8 & 1.35 & 239.1 & 1.07 & 241.1 & 0.87 \\
\hline
\end{tabular}




\section{Relation between $\log \boldsymbol{A}_{0} / \boldsymbol{T}_{0}$ and $\boldsymbol{M}$}

We obtained $\log A_{0} / T_{0}$, that is $\log A / T$ at the epicenter, for many deep earth-

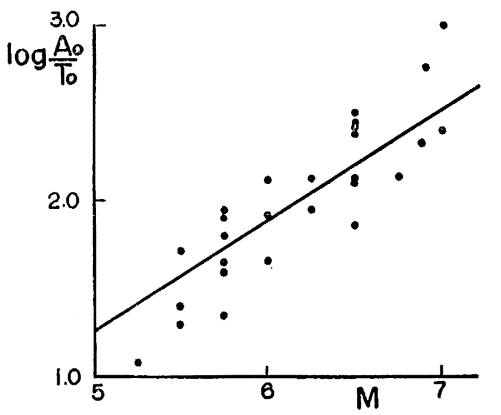

Fig. 5. $\log A_{0} / T_{0}$ with respect to $M$ for the earthquakes, $H=250$ $450 \mathrm{~km}$. Full line shows the values calculated by $\log A_{0} / T_{0}=0.63 M-$ 1. 88 . quakes of which $M$ were given already, using the standard $\log A / T-\Delta$ curves.

We compared $\log A_{0} / T_{0}$ with the corresponding $M$ in the case of deep earthquakes of $H=$ $250-450 \mathrm{~km}$, only because in this range of the depths we had comparatively many examples. The result is shown in Fig. 5.

If we assume a linear relation between $\log A_{0} / T_{0}$ and $M$, we get a formula

$$
\log A_{0} / T_{0}=0.63 M-1.88 \text {, }
$$

by the method of least squares.

A similar equation will be given for shallow earthquakes as follows.

B. Gutenberg and C.F. Richter (1956) obtained the following two relations,

and

$$
m_{B}=0.63 M_{S}+2.5 \text {, }
$$

$$
\log A_{0} / T_{0}=m_{B}-2.3 \text {. }
$$

Combining these formulae, we obtain

$$
\log A_{0} / T_{0}=0.63 M+0.2,
$$

for the Pasadena group of seismological stations.

In general, it is expected that the relation between $\log A_{0} / T_{0}$ and $M$ will be given by a formula, that is

$$
\log A_{0} / T_{0}=0.63 M-\alpha(H),
$$

where, $\alpha(H)$ is a constant for a given focal depth $H$, and will be determined in the next article.

\section{The values of $\alpha(\boldsymbol{H})$}

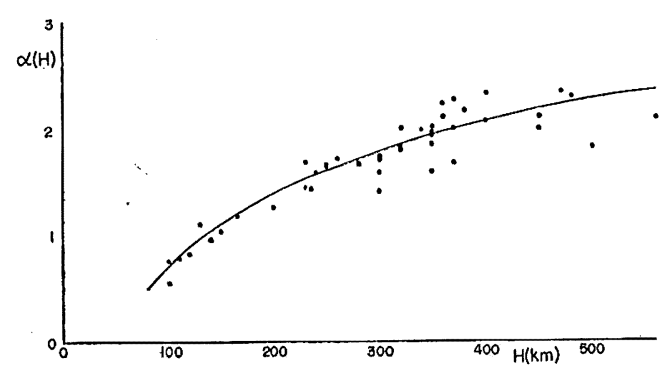

Fig. 6. $\alpha(H)$ with respect to $H$. Full line shows the values calculated by $\alpha(H)=2.5 \log t_{0}-2.8$.
The values of $\alpha(H)$, are obtained by a formula

$$
\alpha(H)=0.63 M-\log A_{0} / T_{0},
$$

using the known $\log A_{0} / T_{0}$ and $M$ of deep earthquakes of various focal depths. They are shown in Fig. 6.

By N. RickeR's wavelet theory, it is expected that $\alpha(H)$ is proportional to $5 / 2 \log t_{0}$, where $t_{0}$ is the travel time of the $S$ phase at the 
epicenter.

In fact, as will be seen from the figure, the values of $\alpha(H)$ obtained above are well represented as a function of $H$ by a formula

$$
\alpha(H)=2.5 \log t_{0}-2.8 .
$$

The values of $\alpha(H)$ calculated by the equation are shown in Table 3.

Table 3. Values of $\alpha(H)$.

\begin{tabular}{|c|c|c|c|c|c|c|c|}
\hline$H \mathrm{~km}$ & 100 & 120 & 160 & 200 & 240 & 280 & 320 \\
\hline$\alpha(H)$ & 0.72 & 0.90 & 1.17 & 1.40 & 1.57 & 1.72 & 1.87 \\
\hline$H \mathrm{~km}$ & 360 & 400 & 450 & 500 & & & \\
\hline$\alpha(H)$ & 1.97 & 2.07 & 2.20 & 2. 28 & & & \\
\hline
\end{tabular}

\section{Comparison between $M^{\prime}$ and $\boldsymbol{M}_{G}$}

We evaluated the magnitudes of deep earthquakes by a formula

$$
0.63 M=\log A_{0} / T_{0}+\alpha(H),
$$

and designated them as $M^{\prime}$.

We compared $M^{\prime}$ with $M_{G}$, that is the $M$ given by the Pasadena seismological laboratory, and found that $M^{\prime}$ coincided well with $M_{G}$ so far as the magnitude does not exceed 7 .

If $M^{\prime}$ exceeds 7 , we must use the other formula

$$
\left\{0.63+0.08\left(\log A_{0} / T_{0}+\alpha(H)-4.4\right)\right\} M=\log A_{0} / T_{0}+\alpha(H)
$$

to reduce $M^{\prime}$ to $M_{G}$.

It seems to the writer that the reason of this change of the formula at $M=7$ may be found in the correction which was applied only to shocks of magnitude 7 or over by the Pasadena seismological laboratory.

$M$ ' obtained by the formulae $(\alpha)$ or $(\beta)$ according as $M^{\prime}$ is smaller or greater than 7 and the corresponding $M_{G}$ are shown in Fig. 7.

As will be seen from the figure, the difference between $M^{\prime}$ and $M_{G}$ is generally within the limits \pm 0.3 unit of magnitude.

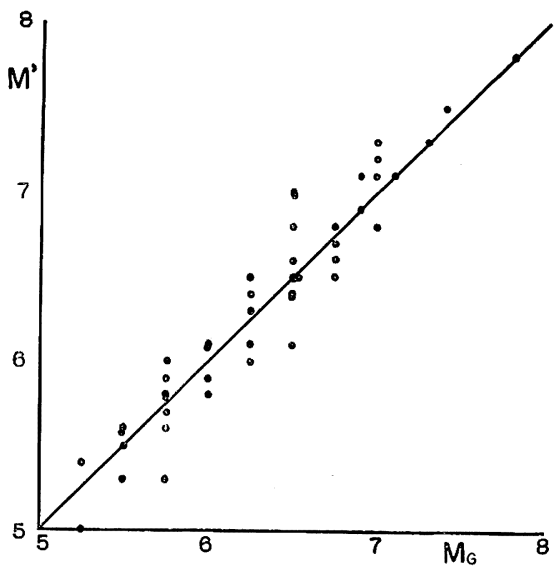

Fig. 7. Comparison between $M^{\prime}$ and $M_{G}$. 
The date of occurrence, the location of the epicenter, the focal depth, $\log A_{0} / T_{0}$, $M^{\prime}$ and $M_{G}$ of all earthquakes used in this investigation are shown in Table 4.

Table 4.

\begin{tabular}{|c|c|c|c|c|c|c|c|c|}
\hline \multirow{2}{*}{ Date } & \multicolumn{2}{|c|}{ (J.S.T.) } & \multicolumn{3}{|c|}{ Epicenter } & \multirow{2}{*}{$\log A_{0} / T_{0}$} & \multirow{2}{*}{$M^{\prime}$} & \multirow{2}{*}{$M_{G}$} \\
\hline & $\mathrm{m}$ & $\mathrm{d}$ & $\lambda\left({ }^{\circ} \mathrm{E}\right)$ & $\varphi\left({ }^{\circ} \mathrm{N}\right)$ & $H \mathrm{~km}$ & & & \\
\hline 1930 & $\begin{array}{l}\text { V } \\
\text { VII }\end{array}$ & $\begin{array}{l}24 \\
23\end{array}$ & $\begin{array}{l}139.9 \\
147\end{array}$ & $\begin{array}{l}34.1 \\
44^{1} / 3\end{array}$ & $\begin{array}{r}100 \sim 120 \\
140\end{array}$ & $\begin{array}{l}3.46 \\
3.50\end{array}$ & $\begin{array}{l}6.8 \\
7.1\end{array}$ & $\begin{array}{l}6^{3 / 4} \\
7.1\end{array}$ \\
\hline 1931 & $\begin{array}{l}\text { I } \\
\text { I } \\
\text { II } \\
\text { III } \\
\text { IV } \\
\text { VI } \\
\text { VI }\end{array}$ & $\begin{array}{r}9 \\
21 \\
20 \\
1 \\
21 \\
2 \\
30\end{array}$ & $\begin{array}{l}140.6 \\
145.6 \\
135.7 \\
143.7 \\
134.2 \\
137.5 \\
136.8\end{array}$ & $\begin{array}{l}39.8 \\
43.4 \\
44.5 \\
46.0 \\
38.5 \\
36.0 \\
33.9\end{array}$ & $\begin{array}{l}130 \\
100 \\
350 \\
250 \\
350 \\
240 \\
350\end{array}$ & $\begin{array}{l}2.67 \\
3.38 \\
3.20 \\
2.45 \\
1.92 \\
2.51 \\
2.13\end{array}$ & $\begin{array}{l}5.8 \\
6.5 \\
7.5 \\
6.5 \\
6.1 \\
6.5 \\
6.5\end{array}$ & $\begin{array}{l}6 \\
6^{1} / 4 \\
7.4 \\
6^{1} / 2 \\
6 \\
6^{1 / 2} \\
6^{1 / 2}\end{array}$ \\
\hline 1932 & $\begin{array}{l}\text { II } \\
\text { IV } \\
\text { V } \\
\text { VII } \\
\text { VII } \\
\text { X } \\
\text { X } \\
\text { XI } \\
\text { XII }\end{array}$ & $\begin{array}{r}19 \\
28 \\
5 \\
25 \\
27 \\
14 \\
26 \\
13 \\
5\end{array}$ & $\begin{array}{l}140.3 \\
136.7 \\
135.3 \\
135.9 \\
139.0 \\
138.8 \\
144.6 \\
136.7 \\
137.0\end{array}$ & $\begin{array}{l}32.9 \\
34.0 \\
34.6 \\
35.2 \\
31.2 \\
31.6 \\
46.2 \\
43.8 \\
33.7\end{array}$ & $\begin{array}{l}150 \\
320 \\
360 \\
360 \\
300 \\
300 \\
370 \\
300 \\
350\end{array}$ & $\begin{array}{l}2.43 \\
1.80 \\
1.86 \\
2.14 \\
1.90 \\
1.72 \\
2.42 \\
3.0 \\
1.65\end{array}$ & $\begin{array}{l}5.6 \\
5.8 \\
6.1 \\
6.5 \\
5.9 \\
5.6 \\
7.0 \\
7.2 \\
5.7\end{array}$ & $\begin{array}{l}5^{1} / 2 \\
5^{3} / 4 \\
6^{1} / 2 \\
6^{3} / 4 \\
5^{3} / 4 \\
5^{1} / 2 \\
6^{1} / 2 \\
7.0 \\
5^{3} / 4\end{array}$ \\
\hline 1933 & $\begin{array}{l}\text { II } \\
\text { V } \\
\text { V } \\
\text { IX }\end{array}$ & $\begin{array}{r}9 \\
24 \\
29 \\
20\end{array}$ & $\begin{array}{l}138.8 \\
145.6 \\
138.0 \\
136.6\end{array}$ & $\begin{array}{l}31.7 \\
46.7 \\
32.4 \\
34.1\end{array}$ & $\begin{array}{l}250 \\
450 \\
400 \\
380\end{array}$ & $\begin{array}{l}2.12 \\
1.66 \\
1.08 \\
1.30\end{array}$ & $\begin{array}{l}5.9 \\
6.1 \\
5.0 \\
5.3\end{array}$ & $\begin{array}{l}6 \\
6 \\
5^{1 / 4} \\
5^{1} / 2\end{array}$ \\
\hline 1935 & $\begin{array}{l}\text { IV } \\
\text { V } \\
\text { X }\end{array}$ & $\begin{array}{l}15 \\
31 \\
15\end{array}$ & $\begin{array}{l}137.1 \\
133.8 \\
135.4\end{array}$ & $\begin{array}{l}36.2 \\
38.5 \\
37.7\end{array}$ & $\begin{array}{l}230 \\
450 \\
280\end{array}$ & $\begin{array}{l}2.25 \\
2.10 \\
1.95\end{array}$ & $\begin{array}{l}6.0 \\
6.8 \\
5.8\end{array}$ & $\begin{array}{l}6^{1 / 4} \\
61 / 2 \\
5^{3} / 4\end{array}$ \\
\hline 1936 & $\begin{array}{l}\text { VI } \\
X \\
X \\
X I\end{array}$ & $\begin{array}{r}26 \\
20 \\
26 \\
1\end{array}$ & $\begin{array}{l}137.9 \\
1351 / 4 \\
136.3 \\
129.0\end{array}$ & $\begin{array}{l}32.5 \\
37.0 \\
34.5 \\
30^{1} / 2\end{array}$ & $\begin{array}{l}320 \\
350 \\
340 \\
230\end{array}$ & $\begin{array}{l}2.13 \\
1.60 \\
1.95 \\
2.65\end{array}$ & $\begin{array}{l}6.4 \\
5.6 \\
6.1 \\
6.6\end{array}$ & $\begin{array}{l}6^{1 / 4} \\
5^{3} / 4 \\
6^{1} / 4 \\
6^{1} / 2\end{array}$ \\
\hline 1937 & $\mathrm{XI}$ & 22 & 135.7 & 35.1 & 370 & 1.35 & 5.3 & $5^{3} / 4$ \\
\hline 1938 & $\begin{array}{l}\text { II } \\
\text { IV } \\
\text { X }\end{array}$ & $\begin{array}{r}7 \\
23 \\
18\end{array}$ & $\begin{array}{l}139.1 \\
130.1 \\
141.3\end{array}$ & $\begin{array}{l}36.1 \\
28.2 \\
44.0\end{array}$ & $\begin{array}{l}100 \\
165 \\
260\end{array}$ & $\begin{array}{l}3.34 \\
2.75 \\
2.38\end{array}$ & $\begin{array}{l}6.4 \\
6.3 \\
6.4\end{array}$ & $\begin{array}{l}6^{1 / 2} \\
6^{1} / 4 \\
6^{1} / 2\end{array}$ \\
\hline 1939 & IV & 21 & 140.0 & 47.6 & 500 & 2.58 & 7.3 & 7.0 \\
\hline 1940 & $\begin{array}{l}\text { VI } \\
\text { VII } \\
\text { VII } \\
\text { XI } \\
\text { XI }\end{array}$ & $\begin{array}{r}27 \\
4 \\
10 \\
7 \\
27\end{array}$ & $\begin{array}{l}138.8 \\
144.5 \\
130.6 \\
138.5 \\
139.5\end{array}$ & $\begin{array}{l}30.6 \\
44.3 \\
44.8 \\
30.3 \\
36.5\end{array}$ & $\begin{array}{l}400 \\
200 \\
560 \\
480 \\
120\end{array}$ & $\begin{array}{l}1.40 \\
2.35 \\
2.50 \\
1.95 \\
2.48\end{array}$ & $\begin{array}{l}5.5 \\
6.0 \\
7.3 \\
6.7 \\
5.4\end{array}$ & $\begin{array}{l}5^{1 / 2} \\
5^{3} / 4 \\
7.3 \\
6^{3} / 4 \\
5^{1} / 4\end{array}$ \\
\hline 1942 & $\begin{array}{l}\text { III } \\
\text { IV }\end{array}$ & $\begin{array}{r}6 \\
20\end{array}$ & $\begin{array}{l}141.7 \\
137.3\end{array}$ & $\begin{array}{l}43.0 \\
33.9\end{array}$ & $\begin{array}{l}300 \\
350\end{array}$ & $\begin{array}{l}2.76 \\
2.50\end{array}$ & $\begin{array}{l}7.1 \\
7.0\end{array}$ & $\begin{array}{l}6.99 \\
61 / 2\end{array}$ \\
\hline 1943 & $\mathrm{XI}$ & 17 & 138.0 & 33.0 & 320 & 2.40 & 6.3 & 7.0 \\
\hline 1950 & II & 28 & 143.8 & 46.0 & 320 & 3.90 & 7.8 & 7.8 \\
\hline 1951 & IV & 17 & 138,0 & 31.2 & 470 & 1.90 & 6.6 & $6^{3} / 4$ \\
\hline 1952 & $\mathrm{~V}$ & 28 & 135.8 & 35.1 & 370 & 2.33 & 6.9 & $6^{3} / 4 \sim 7$ \\
\hline 1954 & $\mathrm{~V}$ & 15 & 137.4 & 36.0 & $230 \sim 240$ & 2.97 & 7.1 & 7 \\
\hline
\end{tabular}




\section{Theoretical considerations on the formula $\log \boldsymbol{A}_{0} / \boldsymbol{T}_{0}=0.63 M-\alpha(\boldsymbol{H})$}

In article 4 , it is shown that the formula

$$
\log A_{0} / T_{0}=0.63 M-\alpha(H)
$$

1s an elementary equation connecting $\log A_{0} / T_{0}$ with $M$.

Now, $A_{0} / T_{0}$ is the ratio of the maximum ground applitude of body waves to the corresponding period at the epicenter, and $M$ is effectively given in terms of $M_{S}$, that is the magnitude determined from the amplitudes of surface waves for shallow teleseisms.

To connect the two quantities $A_{0} / T_{0}$ and $M_{S}$, we must consider theoretically $A / T$ of body waves at the epicenter and the amplitudes of surface waves at a distance produced by a disturbance in the Earth.

Prof. T. SAKAI (1934) treated theoretically the propagation of waves over the plane surface of an elastic solid produced by an internal source.

As a distortional point source, he assumed a primary disturbance which can be written in the form

$$
D_{R}{ }^{(0)}=\frac{2 A \cos \theta}{c^{2} R_{0}{ }^{3}} \frac{1}{\tau^{2}+1}, \quad D_{\theta}{ }^{(0)}=\frac{A \sin \theta}{c^{2} R_{0}{ }^{3}} \frac{1}{\tau^{2}+1},
$$

where

$$
\tau=\left(t-R_{0} / v_{2}\right) / c,
$$

$D_{R}{ }^{(0)}=$ radial component of the displacement at the focus,

$D_{\theta}{ }^{(0)}=$ co-latitudinal component of the displacement at the focus,

$R_{0}=$ radius of a small sphere taken at the focus,

$v_{2}=$ velocity of the distortional wave,

$\theta=$ co-latitude, the polar axis being directed vertically upward from the focus, $A=$ constant.

$c$ may be taken as a measure of the period of the shock wave or the duration of the aperiodic disturbance.

The horizontal and the vertical components of the displacement of the distortional wave near the epicenter can be given respectively as follows;

$$
D_{r}^{(2)}=\frac{4 A \theta_{r}}{v_{2}^{2} d c^{4}} \frac{3 \tau^{2}-1}{\left(\tau^{2}+1\right)^{3}}, \quad D_{z}^{(2)}=-\frac{4 A \theta_{z}}{v_{2}^{2} d c^{4}} \frac{3 \tau^{2}-1}{\left(\tau^{2}+1\right)^{3}},
$$

where

$$
\tau=\left(t-R / v_{2}\right) / c,
$$

$\theta_{r}, \theta_{z}=$ certain functions of $\theta$,

$d=$ depth of the source,

$R=$ hypocentral distance.

If we represent the displacement at the focus by $D^{(0)}$, we have a relation

$$
D_{r}^{(2)} \propto D^{(0)} / c^{2} .
$$

The components of the displacement of the Rayleigh wave at a large epicentral distance are given by 


$$
D_{r}^{(3)}=B_{3} c_{3} \frac{\cos \left(\frac{7}{2} \tan ^{-1} \frac{1}{\tau}\right)}{\left(\tau^{2}+1\right)^{7 / 4}}, \quad D_{z}^{(3)}=-B_{3} \frac{\sin \left(\frac{7}{2} \tan ^{-1} \frac{1}{\tau}\right)}{\left(\tau^{2}+1\right)^{7 / 4}},
$$

where

$$
\begin{aligned}
\tau & =\left(t-r / v_{3}\right) /\left\{c\left(1+\frac{d \delta_{0}{ }^{l}}{c v_{2}}\right)\right\}, \\
B_{3} & =\frac{-15 A \pi \sqrt{ } \overline{v_{3}} \delta_{0}^{\prime} M_{z}\left(-i \delta_{0}^{\prime}\right)}{2^{5 / 2} c^{9 / 2} v_{2}^{3} E^{\prime}\left(-i \delta_{0}^{\prime}\right)\left(1+d \delta_{0}^{\prime} / c v_{2}\right)^{7 / 2} \sqrt{r}}, \\
\delta_{0}^{\prime} & =\left\{\left(\frac{v_{2}}{v_{3}}\right)^{2}-1\right\}^{1 / 2},
\end{aligned}
$$

$c_{3}, M_{z}\left(-i \delta_{0}{ }^{\prime}\right), E^{\prime}\left(-i \delta_{0}{ }^{\prime}\right)=$ certain functions of $v_{1}, v_{2}$ and $v_{3}$, $v_{1}=$ velocity of the dilatational wave, $v_{2}=$ velocity of the distortional wave, $v_{3}=$ velocity of the Rayleigh wave, $r=$ epicentral distance.

If we assume $d / c v_{2} \gg 1$, that is, the depth of the focus is greater than the breadth of the shock wave, we have a relation

$$
D_{r}^{(3)} \infty D^{(0)} c .
$$

After B. Gutenberg (1945), $M_{S}$ is given by

$$
M_{S}=\log A_{S}-\log B+C+D,
$$

where

$A_{S}=$ horizontal component of the maximum ground movement in microns during surface waves having periods of about 20 seconds,

$B=$ the same quantity for a shock of magnitude zero,

$C=$ constant for each station, ground, instrument,

$D=$ depth, azimuth, absorption.

Therefore, we may take

$$
M_{S} \infty \log D_{r}^{(3)},
$$

and we have the following relations :

$$
\log A_{0} / T_{0} \infty \log D_{r}^{(2)} / c \infty \log D^{(0)} / c^{3} \infty \log D_{r}^{(3)} / c^{4} \infty\left(M_{S}-4 \log c\right) .
$$

B. Gutenberg and C. F. Richter (1956) examined the relation between the period of the wave of maximum amplitude and the corresponding $M$, and obtained a result that a rough representation for $M_{L}<7$ is

$$
\log T_{0}=-1.1+0.1 M_{L},
$$

where $M_{L}$ is the magnitude determined from records of local earthquakes in California according to the original definition by RICHTER.

If we use $M_{S}$ instead of $M_{L}$, the formula is transformed approximately to

$$
\log T_{0}=-1.03+0.093 M_{S} \text {. }
$$


Therefore, we may assume

$\log c \infty 0.093 M_{S}$

and have lastly

$\log A_{0} / T_{0} \infty 0.63 M_{S}$

\section{Azimuthal factor for $\log \boldsymbol{A} / \boldsymbol{T}$}

From our experiences, we notice that the $\log A / T$ observed at each station fairly deviates from the standard value at each epicentral distance even after applying the station correction.

To examine whether there is any azimuthal factor among the observed $\log A / T$ or not, the writer calculated the amount of the deviation, that is

$$
\Delta \log A / T=(\log A / T)_{\mathrm{obs}}-(\log A / T)_{\mathrm{cal}},
$$

and plotted it on a geographical map.

Some examples are shown in Figs. 8-12. As will be seen from these figures, the geographical distributions of $\Delta \log A / T$ are rather systematic, and we can separate the stations with positive $\Delta \log A / T$ from those with negative one by one or two lines.

Moreover, in these figures the nodal lines of initial motions of the $P$ phase taken mainly from the paper given by H. Honda and A. Masatsuka (1952) are also shown.

It seems to the writer that one of the nodal lines frequently goes through the midst of the domains with nagative $\Delta \log A / T$.

The points of intersection of the lines, $P$ and $P^{\prime}$ as shown in Figs. 9-11, do not coincide with each other. The polar angle $\theta$ between $P$ and $P^{\prime}$, taking the origin of the polar coordinates at the focus, was calculated by

$$
\cos \theta=\cos \theta_{p} \cos \theta_{p},+\sin \theta_{p} \sin \theta_{p}, \cos \varphi,
$$

where

$$
\begin{aligned}
& \sin \theta_{p}=\frac{r_{0}}{r} \frac{v}{v_{0}} \alpha_{p}, \sin \theta_{p},=\frac{r_{0}}{r} \frac{v}{v_{0}} \alpha_{p}, \\
& \quad \alpha_{p}=\text { cosine of the emergent angle } \\
& \text { at } P,
\end{aligned}
$$

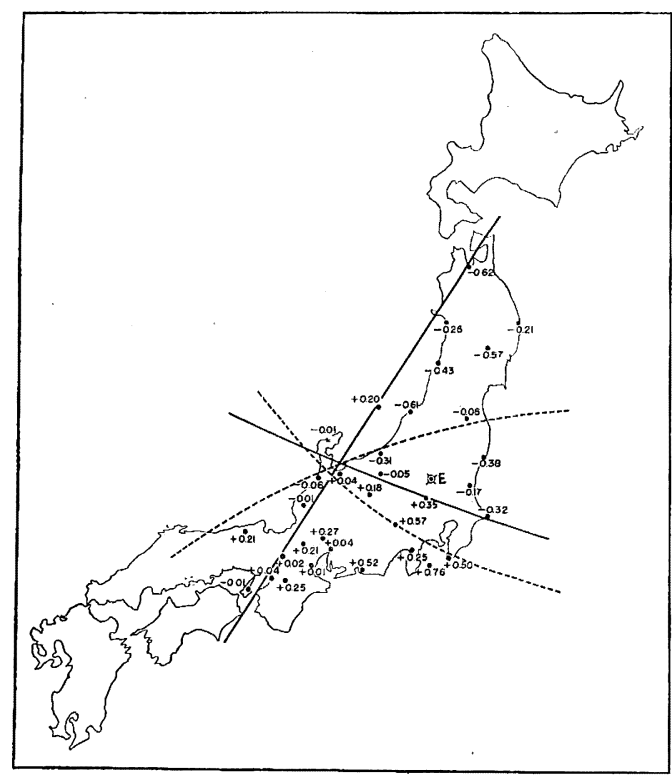

Fig. 8. Geographical distribution of $\Delta \log A / T$ of the earthquakes on November 27, 1940, $H=120 \mathrm{~km}$. Full lines represent the boundaries between positive and negative values. Dotted lines represent the nodal lines of initial motions of the $P$ phase. 


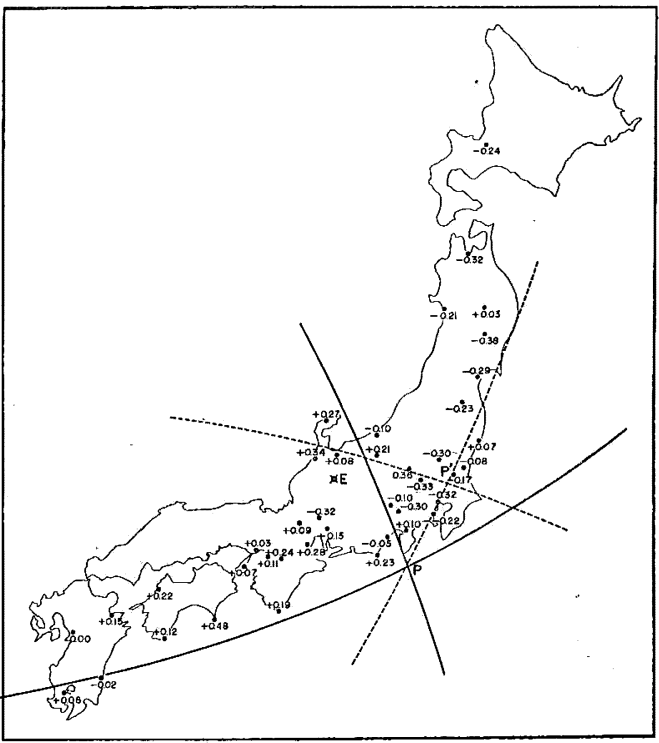

Fig. 9. Geographical distribution of $\Delta \log A / T$ of the earthquake ion April 15, 1935, $H=230 \mathrm{~km}$.

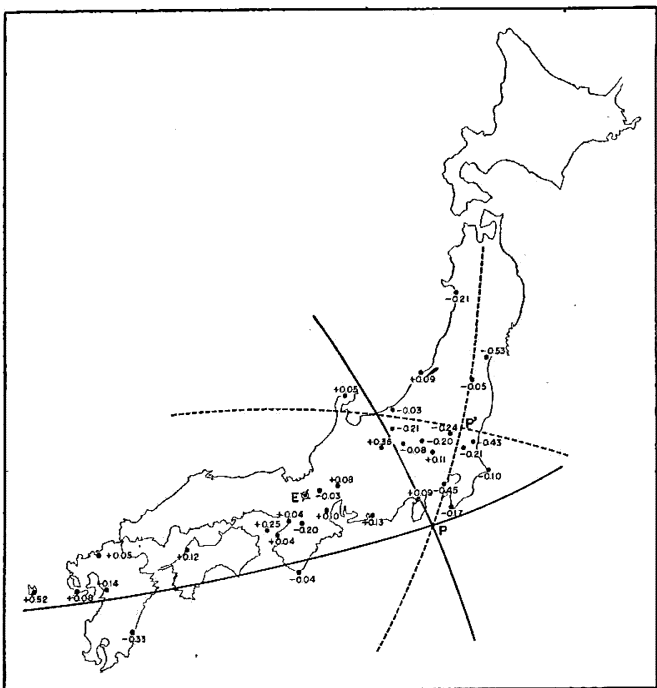

Fig. 11. Geographical distribution of $\Delta \log A / T$ of the earthquake on July $25,1932, H=360 \mathrm{~km}$.

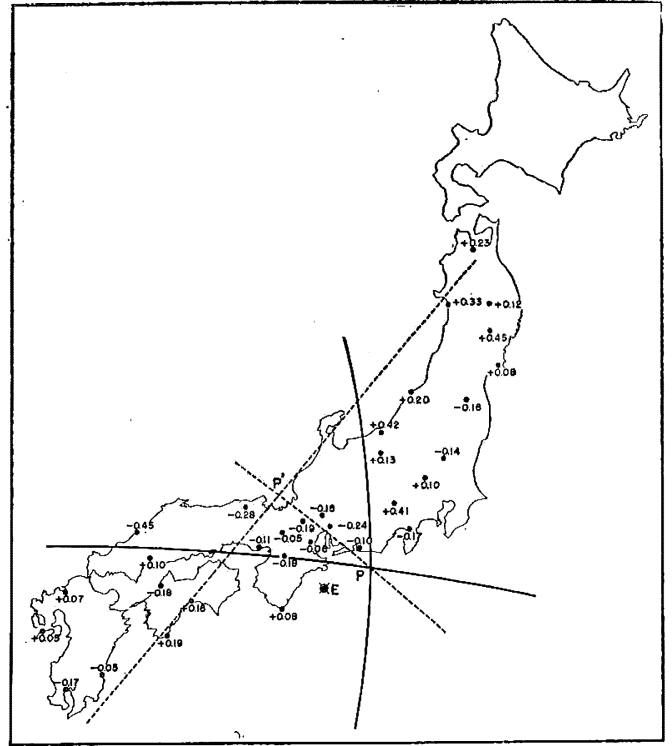

Fig. 10. Geographical distribution of $\Delta \log A / T$ of the earthquake on June $30,1931, H=350 \mathrm{~km}$.

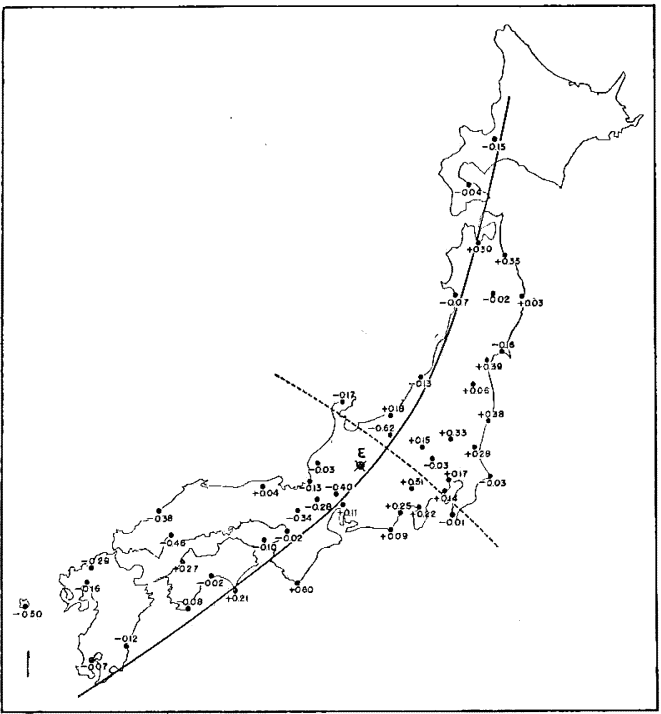

Fig. 12. Geographical distribution of $\Delta \log A / T$ of the earthquake on May 15, 1954, $H=230$ $240 \mathrm{~km}$. Full line represents the boundary between positive and negative values. Dotted line represents the nodal line of initial motions of the $P$ phase. 
$\alpha_{p},=$ cosine of the emergent angle at $P^{\prime}$,

$r_{0}=$ radius of the Earth,

$r=$ radial distance of the focus from the center of the Earth,

$v_{0}=$ wave velocity near the surface,

$v=$ wave velocity at the focus,

$\varphi=$ angle between two lines $E P$ and $E P^{\prime}$, connecting $P$ and $P^{\prime}$ to the epicenter $E$ respectively.

The polar angles take values between $30^{\circ}-40^{\circ}$ in cases shown in the figures.

From these examples and some others not shown here, the writer is inclined to accept the reality of the azimuthal factor for $\log A / T$.

Sometimes, the observed $\log A / T-\Delta$ curves were much deformed from the standard curve by the azimuthal factor, so that we must use sufficient data obtained by many earthquakes to determine the standard $\log A / T-\Delta$ curve for an earthquake of any given depth.

Although the existence of the azimuthal factor for $\log A / T$ is not yet thoroughly proved, some examples such as shown above seem to suggest that the azimuthal factor might have some intimate connections with the mechanism of the occurrence of the earthquakes.

H. KaWAsum $(1933,1934)$ gave the displacements of $P$ wave and $S$ wave due to a doublet force with moment respectively as follows;

$$
\begin{aligned}
u_{1} & =A \frac{d}{d r}\left\{\frac{H^{(2)}{ }_{2+1 / 2}(h r)}{\sqrt{r}}\right\} \sin ^{2} \theta \sin 2 \varphi e^{i p t} \\
& \approx-\sqrt{\frac{2 h}{\pi}} A \frac{e^{i(p t-h r)}}{r} \sin ^{2} \theta \sin 2 \varphi \\
v_{1} & =A \frac{H^{(2)}{ }_{2+1 / 2}(h r)}{r^{3 / 2}} 2 \sin \theta \cos \theta \sin 2 \varphi e^{i p t} \approx O\left(\frac{1}{r^{2}}\right), \\
w_{1} & =A \frac{H^{(2)} \frac{2+1 / 2}{r^{3 / 2}}(h r)}{2} \sin \theta \cos 2 \varphi e^{i p t} \approx O\left(\frac{1}{r^{2}}\right), \\
u_{2} & =B \frac{H^{(2)}{ }_{2+1 / 2}(k r)}{r^{3 / 2}} \frac{3}{2} \sin ^{2} \theta \sin 2 \varphi e^{i p t} \approx O\left(\frac{1}{r^{2}}\right), \\
v_{2} & =B \frac{1}{r} \frac{d}{d r}\left\{\sqrt{r} H^{(2)}{ }_{2+1 / 2}(k r)\right\} \frac{1}{2} \sin \theta \cos \theta \sin 2 \varphi e^{i p t} \\
& \approx \sqrt{\frac{2 k}{\pi}} B^{\frac{e^{i(p t-k r)}}{r}} \frac{1}{2} \sin \theta \cos \theta \sin 2 \varphi, \\
w_{2}= & B\left\{\frac{k H^{(2)}{ }_{2+1 / 2}(k r)}{\sqrt{r}} \sin { }^{2} \varphi+\frac{1}{r^{3 / 2}} H^{(2)}{ }_{2+1 / 2}(k r) \cos 2 \varphi\right\} \sin \theta e^{i p t} \\
& \approx \sqrt{\frac{2 k}{\pi}} B \frac{e^{i(p t-k r)}}{r} \sin \theta \sin ^{2} \varphi,
\end{aligned}
$$

where, $u_{1}, v_{1}, w_{1}$ are displacements of $P$ wave and $u_{2}, v_{2}, w_{2}$ are displacements of $S$ wave in the direction of $r, \theta$ and $\varphi$ respectively.

The nodal planes of $P$ wave are $2 \varphi=0$ and $\pi$. There is a nodal plane $\varphi=0$ or 
$\pi$ for $S$ wave, and this is coincident with one of the nodal planes of $P$ wave and corresponds to the fault plane.

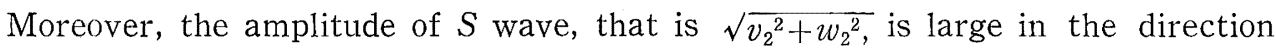
perpendicular to the fault plane.

In the above examples, the nodal line of $P$ wave which passes through the negative $\Delta \log A / T$ domain might be considered as a locus of the intersection of the fault plane with the Earth's surface. But we cannot understand why $P$ and $P^{\text {' }}$ do not coincide with each other.

\section{Summary}

The writer tried to obtain the same $M$ as those given by the Pasadena seismological laboratory for the deep-focus earthquakes in and near Japan by using the seismological data obtained at Japanese stations. The results are summarized in the following.

(1) It is shown that the calculated $\log A / T-\Delta$ curves for deep earthquakes of various depths on the basis of NoRman Ricker's wavelet theory fit well with the observed values.

(2) It is shown that the magnitude of deep earthquakes can be evaluated by the formula

$$
\text { 0. } 63 M=\log A_{0} / T_{0}+\alpha(H)
$$

so far as the magnitude does not exceed 7 .

If $M$ exceeds 7 , we must use the other formula

$$
\left\{0.63+0.08\left(\log A_{0} / T_{0}+\alpha(H)-4.4\right)\right\} M=\log A_{0} / T_{0}+\alpha(H),
$$

where $A_{0} / T_{0}$ is the amplitude/period ratio at the epicenter. And $\alpha(H)$ is given by the formula

$$
\alpha(H)=2.5 \log t_{0}-2.8,
$$

where $t_{0}$ is the travel time of the $S$ phase at the epicenter.

(3) It is shown that the station corrections for deep earthquakes are quite different from those for shallow earthquakes. The former reflect deeper geological structures around each station than do the latter.

(4) Some examples are shown to suggest that these is the azimuthal factor among the observed $\log A / T$, and it is shown that the factor may be explained to some extent by assuming a doublet force with moment as the disturbance at the hypocenter.

(5) Some theoretical considerations are made on the relation between $\log A_{0} / T_{0}$ and $\log A_{S}$. Where $A_{S}$ is the amplitudes of surface waves, and $M_{S}$ is defined to be proportional to $\log A_{s}$.

Taking the relation between the period of the wave of maximum amplitude and the corresponding $M$ into consideration, the formula 


$$
\log A_{0} / T_{0}=0.63 M-\alpha(H)
$$

is proved theoretically to some extent, where $M$ is given effectively in terms of $M_{S}$.

Acknowledgements-The writer wishes to express his hearty thanks to Dr. Y. KoDAIRA for reviewing the manuscript.

\section{References}

Gutenberg B., 1945: Amplitudes of surface waves and magnitudes of shallow earthquakes. Bull. Seis. Soc. Am., 35, 3.

Gutenbera B. and Richter C.F., 1954: Seismicity of the earth and related phenomena. 2nd Ed., Princeton University Press, Princeton, N.Y.

Gurenberg B. and Riohter C.F., 1956: Earthquake magnitude, intensity, energy, and acceleration (Second Paper). Bull. Seis. Soc. Am., 46, 105-145.

Gutenbera B. and Richter C.F., 1956: Magnitude and energy of earthquakes. Annali di Geofisica, 9, 1.

Hirono T. and IwaI Y., 1952: A Method of determination of magnitudes for deep earthquakes. Quarterly Jour. Seismology, 16, No. 3-4, 14-22.

Hond H., 1951: Amplitudes of $P$ and $S$, magnitude and energy of deep earthquakes. Sci. Rep. Tòhoku Univ., Ser. 5, Geophys., 3, 138-143.

HoNdA H. and MASATSUKA A., 1952: On the mechanisms of earthquakes and the stresses producing them in Japan and its vicinity. 'Sci. Rep. Tôhoku Univ. Ser. 5, Geophys., $4,42-60$.

ICHIKAWA M., 1958: Regional corrections of earthquake magnitude for every station in Japan. Quarterly Jour. Seismology, 22, 179-186.

Katsumata K., 1958: A method of determination of magnitude for near and deep-focus earthquakes. Quarterly Jour. Seismology, 22, 173-177.

Kawasum H., 1933: Study on the propagation of seismic waves. (The second paper) Amplitude of seismic waves with the structure of the earth's crust and mechanisms of their origin. Bull. Earthq. Res. Inst., 11, 403-453.

KaWasumr H., 1934: Study on the propagation of seismic waves. (The second paper) (Continued). Bull. Earthq. Res. Inst., 12, 660-705.

RICKeR, N., 1949: Attenuations and amplitudes of seismic waves. Trans. Am. Geophys. U., 30, 184-186.

Sagisaka K. and Takehana M., 1935: Tables of the travel time of $S$ and the duration of preliminary tremor. Quarterly Jour. Seismology, 8, 149-161.

SAKAI T., 1934: On the propagation of tremors over the plane surface of an elastic solid produced by an Internal Source. Geophy. Mag. 8, 1-71.

Wadati K. and Hirono T., 1956: Magnitude of earthquakes-especially of near, deep-focus earthquakes. Geophys. Mag., 27, 1-10. 


\title{
日本附近の深発地震の規模について
}

\author{
井上宇 㻆
}

日本の地震観測の資料から深発地震の規模を求めるといろ試みは, 既飞和達, 本多, 厇野, 岩斗, 勝又 そよつてなされている。

然し，地球上層の地震波の速度分布，波動の減衰係数の分布などが十分分つていないばかりでなく，波 動減衰の機煹す明確でない。また, 地震動飞対する地艋補正も, 深発地祳では異常震域を伴うので当然浅 発地震の場合とは異なる筈である。

な抆，発震機構によつて奏体波の振幅の方位差も考えられるので，蛇足のようであるが，この問題を取 报つてみた。

主な結果は次のようなあのである。

(1) NORMAN RIOKER の連波説によつて計算した $\log A / T-\Delta$ 曲楾は観测値と比較的よく一致する。

(2) $M \leqq 7$ の場合は

$$
0.63 M=\log A_{0} / T_{0}+\alpha(H)
$$

によつて,

$M>7$ の昜合は

$\left\{0.63+0.08\left(\log A_{0} / T_{0}+\alpha(H)-4.4\right)\right\} M=\log A_{0} / T_{0}+\alpha(H)$

によつて深発地震の $M$ が求められる。

但し, $\alpha(H)$ は深さによつて暴なる常数であつて, $\alpha(H)=2.5 \log t_{0}-2.8$

とよつて与えられる。

此処飞, $A_{0} / T_{0}$ は震央飞特ける $A / T$ の值であり， $t_{0}$ は震央飞敊ける $S$ 相の走侍である。

(3) 深発地震に対する地盤補正は浅発地祳に対するものと著しく異なつている。

（4）観测される $\log A / T$ は祳源に和ける方位に関係があり，断層面に淔角の方向に大きくなつている ようである。

(5) $M$ を求めるとさの基本となる

$$
\log A_{0} / T_{0} \infty 0.63 M
$$

という関係注，坂井の半無限弾性体の内部震源のある場合の波動理諭飞よつて説明される。

然し，最も大事な地球上層の地震波の速度分布扔よび波動の減衰係数の分布は将来の問題として残され ている。 